\title{
Trunk Pyoderma in a Male Ceylon Elephant (Elephas maximus maximus)
}

\author{
R. VODIČKA \\ The Prague Zoological Garden, Prague, Czech Republic \\ Received June 27, 2007 \\ Accepted December 19, 2007
}

\begin{abstract}
Vodička R.: Trunk Pyoderma in a Male Ceylon Elephant (Elephas maximus maximus). Acta Vet. Brno 2008, 77: 127-131.

The study describes the therapy of purulent trunk dermatitis in an aggressive male Ceylon elephant (Elephas maximus maximus). The elephant was immobilized 4 times with $1.7 \mathrm{ml}$ Large Animal (LA) Immobilon i.m. within 50 days. The anaesthetic action was antagonised with $1.7 \mathrm{ml}$ LA Revivon $+8.0 \mathrm{ml}$ Naloxone i.v. and $0.5 \mathrm{ml}$ LA Revivon $+6.0 \mathrm{ml}$ Naloxone i.m. From skin lesions the following pathogens were isolated: Staphylococcus spp., Streptococcus spp. and Candida tropicalis. Local therapy consisted of the debridement of the affected skin, application of antibiotics and skin antiseptics. Depot penicillin, vitamins, probiotics and autogenous yeast vaccine were administered generally. In haematological indicators the biggest changes were found in the numbers of white blood cells and segmented neutrophils. Markedly low zinc concentrations were found repeatedly. Despite the non-standard steps we took (repeated anaesthesia during a short time, non-compliance with the recommendations for the administration of some drugs, etc.) and difficult handling (aggressive, uncontrollable elephant, no restraint chute), it proved possible to treat such a case in this manner.
\end{abstract}

Proboscidea, purulent dermatitis, anaesthesia, haematology, biochemistry

Disorders of the integument are extremely common in elephants, and account for approximately one third of the total medical cases (Mikota et al. 1994b). They include minor traumas (lacerations, abrasions), abscesses, fistula, masses, dermatitis and dermatosis, papillomas and hyperkeratosis (Mikota et al. 1994b; Rüedi 1995). Mikota et al. (1994b) describe in their long-term study 200 cases of dermatitis in 115 animals. The aetiology was unknown in 163 cases, 12 cases were considered to have an environmental aetiology (e.g. sunburn), 9 were traumatic, 9 were associated with infectious agents, and the rest were due to other causes (e.g. zinc deficiency). Only 5 animals were diagnosed with pyoderma. The most frequently isolated organisms were Staphylococcus, Streptococcus and Candida. Treatment was initiated in 147 cases. Only in 18 patients more than one course of treatment was necessary. In the majority of cases, topical preparations $(n=131)$ were used. In some cases, additional treatment was necessary, including lavage, debridement, anti-inflammatory drugs and injectable antibiotics. The authors recorded also 4 cases of adverse reactions to treatment.

The objective of this case report was to extend knowledge on an optimum treatment process in an aggressive male elephant, managed in a hands-off system.

\section{Case Report and Therapeutic Approach}

On the $20^{\text {th }}$ and $21^{\text {st }}$ of July 1998 the male elephant Kadíra consumed less food than usual. During a close examination, signs of an injury or a contusion of the ventral part of the trunk were found. The trunk was slightly paretic, and the elephant found it difficult to grasp food. Our initial treatment consisted of B-compositum plv. (Vitamins B1, B2, B6, B12, Niacinamid, Pantotenan, Biotin, Inositol, Biofaktory Praha s. r. o., Praha, Czech

Address for correspondence:

MVDr. R. Vodička

The Prague Zoological Garden

U Trojského zámku 3/120

17100 Praha 7, Czech Republic
Phone: + 420296112145

Fax: + 420233556704

E-mail:vodicka@zoopraha.cz

http://www.vfu.cz/acta-vet/actavet.htm 
Republic) and Ecovit plv. (Enterococcus faecium M-74, vitamins A, D3, E, B2, B12, C, H, Medipharm CZ, s.r.o., Hustopeče u Brna, Czech Republic). On the $23^{\text {rd }}$ of July, the elephant started to consume more food and to move his trunk normally. However, the skin on his trunk from the base to the tip of the trunk was chapped, full of rhagades containing pus. Betadine drm. sol. (Povidonum iodinatum, Egis Pharmaceuticals Ltd., Budapest, Hungary) was applied locally using a garden sprayer and C-compositum plv. (Vitamin C, Biofaktory Praha, s. r. o., Praha, Czech Republic) was supplemented to the food. Since the elephant did not like the spraying, all the four following treatments had to be performed under full anaesthesia (Kock et al. 1993; Mikota et al. 1994a; Fowler 1995).

On the $30^{\text {th }}$ of July 1998 Kadíra was immobilized for the first time. His body weight was estimated to be 3.5 tons. Large Animal Immobilon inj. (Etorphine hydrochloride/ Acepromazine maleate, C-Vet Veterinary Products, Leyland, UK) dosed $1.7 \mathrm{ml}$ pro toto i.m. was used for all four anaesthesias. Within 15 minutes the elephant was in lateral recumbency. No complications occurred during the 52 minutes of anaesthesia.

Firstly, the elephant was hosed with water and cleaned from dirt. Then the extent of the skin affection was assessed. The skin on his trunk was affected the most, being chapped from the base to the tip of the trunk, very dry and undermined with yellow pus. The skin on the tail base was chapped, too, with several purulent foci. Before spraying the elephant, samples were taken from the affected spots to perform a bacteriological analysis. Then the damaged skin and pus were removed mechanically. Finally, the elephant was hosed once again and the affected spots were treated with diluted Betadine drm. sol. (1: 10 dilution). Also an antibiotic spray Aueromycin G.V. spray (Chlortetracyclini hydrochloridum, Fort Dodge Animal Health, Southampton, USA) was applied on the lesions. A depot form of penicillin (Penicilin Biotika Depot inj., Benzanthini benzylpenicillinum, Procaini benzylpenicillinum, Biotika, Slovenská L'upča, Slovak Republic) with multivitamins (Duphafral Multi inj., Vitamins A, D3, E, B1, B2, B6, B12, B3, Panthenolum, Fort Dodge Animal Health, Southampton, USA) and selenium (Selevit inj., vitamin E, Natrii selenis, anhydricus, Biotika, Slovenská L'upča, Slovak Republic) were added i.m. as an antibiotic screen. To reverse the anaesthetic, we applied Large Animal Revivon inj. (Diprenorphine hydrochloride, C-Vet Veterinary Products, Leyland, UK) and Naloxone WZF Polfa inj. (Naloxoni hydrochloridum, WZF Polfa S.A., Warszawa, Poland), injected both i.v. (Revivon $1.7 \mathrm{ml}+$ Naloxone $8.0 \mathrm{ml}$ ) and i.m. (Revivon $0.5 \mathrm{ml}+$ Naloxone $6.0 \mathrm{ml}$ ). Within 13 minutes from the application, the elephant stood up and responded normally. Bacteriological analysis revealed the presence of the following pathogens:

Inner side of the ear:

Staphylococcus aureus

Staphylococcus hyicus

Streptococcus agalactiae (group B)

Tip of the trunk:

Staphylococcus aureus

Streptococcus agalactiae (group B)

Tail:

Staphylococcus hyicus

Streptococcus agalactiae (group B)

Streptococcus pyogenes (group A)

As the sensitivity of these pathogens to antibiotics (Olsen 1998) had been determined, we could choose from a wide range of antibiotics, such as Penicillin, Oxacillin, Chloramphenicol, Amoxicillin/Clavulenic acid, Clindamycin, and Bacitracin. However, the elephant could not be treated every day, as he responded aggressively. Due to 
safety reasons a standing sedation for the following treatments was not an option, since the Prague Zoological Garden does not have a restraint chute for elephants. The most feasible treatment (Rüedi 1995) would have been the administration of oral antibiotics, but we wanted to avoid stress on the elephant's gastrointestinal tract. Therefore, the elephant was hosed every day under protected contact. The trunk was washed carefully in order not to remove the antibiotic layer. Probiotics (Ecovit) and vitamins B and C were supplemented to the elephant's food.

Kadíra was immobilized again on the $13^{\text {th }}$ of August for a visual assessment. Samples for a bacteriological analysis and blood were taken. The elephant was hosed with water to assess the condition of the affected skin. There were signs of slight improvement on the trunk and behind the ears. The extent of the affection was reduced. In addition, several foci were found on the right thigh and in the area of the right shoulder blade. Compared to the affection of the trunk, however, these foci were only minor. Again, the altered skin was removed and the pus brushed off with a Betadine-containing solution. Then the elephant was again hosed and Peroxyderm shampoo (Benzoylis peroxidum, Vétoquinol s.r.o., Nymburk, Czech Republic) was applied for 15 minutes before rinsing it with water. Finally, Aureomycin GV and Chronicin (Chloramphenicolum, Spofa Praha, Praha, Czech Republic) sprays were applied on the affected spots and depot penicillin and vitamins were injected. The bacteriological analysis revealed the presence of the same pathogens as those found during the first analysis plus Candida tropicalis. The presence of Candida tropicalis was not massive, yet upon a consultation with an expert, we decided to prepare an autogenous vaccine.

On the $27^{\text {th }}$ of August Kadíra was immobilized for the third time. This time the elephant remained in the position of a sitting dog. Since the elephant did not lie down in a sternal position, there was no pressure against his lungs. Only at the end of anaesthesia he was pushed into lateral recumbency to make it easier for him to stand up after anaesthesia. We re-examined the altered foci to find that healing progressed successfully and the extent of the skin affection was decreased.

On the $3^{\text {rd }}$ and $11^{\text {th }}$ of September, we applied a yeast vaccine to the elephant. The final veterinary follow-up took place on the $17^{\text {th }}$ of September. The anaesthesia was the same with the elephant in lateral recumbency. The skin on his tail, pelvic limb and shoulder blade had fully healed. There was only a minor focus behind his right ear without any pus. Even the trunk healed well, except for the dorsal part, where the entire treatment was repeated one more time. Later, the condition of the skin on his trunk and ears was monitored by adspection. Probiotics and vitamins were supplemented to the elephant's diet for additional 14 days. The skin fully healed in several weeks without further anaesthesia or drug application. The elephant was hosed regularly to ensure that his skin remained supple and did not dry out. (For figures of all immobilizations see Plate XIV-XVI.)

\section{Discussion}

In elephants, purulent dermatitis (Mikota et al. 1994b) of the trunk or other parts of the body is quite rare. Treatment (Salzert 1976; Rüedi 1995) is not difficult if the elephant is used to a daily contact. However, it may be rather complicated if the elephant is aggressive and there is no restraint chute to handle or immobilize the animal. In this case, we decided to apply a non-standard treatment, fully aware of the risks of frequent anaesthesias (Kock et al. 1993; Fowler 1995) and related complications. Also the application of antibiotics (Olsen 1998) was not in compliance with the recommended periods for repeated application. Yet, the problem was treated successfully with the confirmation of an obvious decrease in numbers of WBC, lymphocytes and segmented neutrophils. Still, the primary cause of this purulent dermatitis remains unclear. One of the explanations might be that 
Table 1. Haematological and biochemical changes during repeated treatment

\begin{tabular}{|c|c|c|c|c|c|}
\hline Indices/Day & 30.7 .98 & 13.8 .98 & 27.8 .98 & 17.9. 98 & Refer. \\
\hline WBC $\left(\times 10^{9} / 1\right)$ & 16.30 & 11.80 & 13.60 & 8.60 & 14.78 \\
\hline $\mathrm{RBC}\left(\times 10^{12} / 1\right)$ & 2.88 & 3.42 & 2.80 & 3.04 & 3.11 \\
\hline $\mathrm{Hb}(\mathrm{g} / \mathrm{l})$ & & 126.50 & 106.60 & 139.00 & 133.00 \\
\hline $\mathrm{Ht}(1 / 1)$ & 0.40 & 0.48 & 0.37 & 0.43 & 0.38 \\
\hline $\operatorname{Lym}\left(\times 10^{9} / 1\right)$ & 7.50 & 6.37 & 6.94 & 4.21 & 5.69 \\
\hline $\operatorname{Seg}\left(\times 10^{9} / 1\right)$ & 8.48 & 4.01 & 6.26 & 3.96 & 5.09 \\
\hline Mon $\left(\times 10^{9} / 1\right)$ & 0.16 & 0.94 & 0.14 & 0.26 & 3.21 \\
\hline $\operatorname{Eos}\left(\times 10^{9} / 1\right)$ & 0.16 & & & & 0.52 \\
\hline Bands $\left(\times 10^{9} / 1\right)$ & & 0.47 & 0.27 & 0.17 & 1.21 \\
\hline $\mathrm{TP}(\mathrm{g} / \mathrm{l})$ & 93.30 & 97.90 & 106.30 & 106.10 & 80.00 \\
\hline $\mathrm{Alb}(\mathrm{g} / \mathrm{l})$ & 38.90 & 38.90 & 39.70 & 40.20 & 33.00 \\
\hline Glob (g/l) & 54.40 & 59.00 & 66.60 & 65.90 & \\
\hline Glu (mmol/l) & 2.45 & 2.43 & 4.60 & 4.33 & 6.90 \\
\hline Creat $(\mu \mathrm{mol} / \mathrm{l})$ & 165.20 & 178.40 & 161.70 & 165.60 & 115.00 \\
\hline Urea $(\mathrm{mmol} / \mathrm{l})$ & 3.89 & 4.51 & 4.91 & 5.19 & 3.75 \\
\hline $\operatorname{ALP}(\mu \mathrm{kat} / \mathrm{l})$ & 2.49 & 2.95 & 2.72 & 1.88 & 2.92 \\
\hline $\operatorname{ALT}(\mu \mathrm{kat} / 1)$ & 0.12 & & 0.10 & 0.05 & 0.09 \\
\hline AST $(\mu \mathrm{kat} / \mathrm{l})$ & 0.48 & 0.47 & 0.37 & 0.35 & 0.33 \\
\hline GMT $(\mu \mathrm{kat} / \mathrm{l})$ & 0.38 & 0.26 & 0.26 & 0.18 & 0.18 \\
\hline Trigl (mmol/l) & 0.46 & 0.62 & & & 0.45 \\
\hline Chol (mmol/1) & 0.89 & 1.30 & 1.12 & 1.31 & 1.35 \\
\hline $\mathrm{Na}(\mathrm{mmol} / \mathrm{l})$ & 147.00 & 140.00 & 138.00 & 139.00 & 130.00 \\
\hline $\mathrm{K}(\mathrm{mmol} / \mathrm{l})$ & 4.89 & 4.95 & 4.35 & 3.91 & 5.00 \\
\hline $\mathrm{Ca}(\mathrm{mmol} / \mathrm{l})$ & 2.65 & 2.44 & 2.53 & 2.66 & 2.85 \\
\hline $\mathrm{P}(\mathrm{mmol} / \mathrm{l})$ & 2.1 & 1.9 & 1.87 & 1.89 & 1.9 \\
\hline $\mathrm{Cl}(\mathrm{mmol} / \mathrm{l})$ & 91.80 & 88.20 & 94.00 & 96.60 & 85.00 \\
\hline $\mathrm{Zn}(\mu \mathrm{mol} / \mathrm{l})$ & 9.52 & 11.02 & 8.16 & 8.94 & 19.50 \\
\hline $\mathrm{Cu}(\mu \mathrm{mol} / \mathrm{l})$ & 22.94 & 21.08 & 17.73 & 18.84 & 17.00 \\
\hline $\mathrm{Mg}(\mathrm{mmol} / \mathrm{l})$ & 0.75 & 0.83 & 0.88 & 0.90 & 0.85 \\
\hline $\operatorname{Bil}(\mu \mathrm{mol} / \mathrm{l})$ & 5.30 & 3.40 & 2.70 & 4.50 & 3.40 \\
\hline CK $(\mu \mathrm{kat} / \mathrm{l})$ & 2.10 & 2.50 & 1.73 & 1.87 & 6.00 \\
\hline $\mathrm{LDH}(\mu \mathrm{kat} / \mathrm{l})$ & 10.68 & 12.20 & 9.26 & 7.35 & 18.33 \\
\hline
\end{tabular}

WBC - white blood cell, RBC - red blood cell, Hb - haemoglobin, Ht - haematocrit, Lym - lymphocytes, Seg - segmented neutrophils, Mon - monocytes, Eos - eosinophils, Bands - neutrophilic bands, TP - total protein, Alb - albumin, Glob - globulin, Glu - glucose, Creat - creatinine, ALP - alkaline phosphatase, ALT - alanine aminotransferase, AST - aspartate aminotransferase, GMT - gamma-glutamyltransferase, Trigl - triglyceride, Chol - cholesterol, $\mathrm{Na}$ - sodium, $\mathrm{K}$ - potassium, $\mathrm{Ca}$ - calcium, $\mathrm{P}$ - phosphorus, $\mathrm{Cl}$ - chloride, $\mathrm{Zn}$ - zinc, $\mathrm{Cu}$ - copper, $\mathrm{Mg}$ - magnesium, Bil - total bilirubin, CK - creatine kinase, LDH - lactate dehydrogenase

Refer. - values given as mean, Baronetzky-Mercier (1992), Schmitt (2003)

Kadíra did not have a water pool in his run and was not showered as often as the females. In addition, Kadíra was in musth and gave vent to his rage by bumping and stumbling against the walls inside his house and in his run. The continuity of the skin could have been disturbed as a result and the skin infected from the environment. We also considered the possibility of the infection resulting from Kadíra's rubbing against a fresh painting on the wall of his house but the painting used had already dried up and the paint manufacturer guaranteed no adverse effects on the elephant's health. Thus, the most probable cause for the pyoderma was insufficient humidification of Kadíra's skin. In fact, Asian elephants spend many hours a week bathing in water. Another cause of the pyoderma could be the 
low zinc concentration in serum. Comparing Kadíra's zinc concentration to the values in elephants in the Baronetzky-Mercier's (1992) study, obviously the zinc concentration in our elephant were deeply below physiological limits. Zinc deficiency leads very often to immunodeficiency and to the typical skin alterations (parakeratosis, skin infection and impairment of the wound healing). It is therefore necessary to correct and monitor the elephant's feeding ration and provide sufficient zinc supply also with the addition of suitable feeding supplements.

\section{Pyodermie chobotu samce slona cejlonského (Elephas maximus maximus)}

Práce popisuje terapeutické zvládnutí pyodermie chobotu u agresivního samce slona cejlonského (Elephas maximus maximus). Slon byl $4 \times$ imobilizován 1,7 ml LA Immobilon IM v rozmezí 50 dnů. Účinek anestetik byl antagonizován 1,7 ml LA Revivon $+8,0 \mathrm{ml}$ Naloxone IV a 0,5 $\mathrm{ml}$ LA Revivon $+6,0 \mathrm{ml}$ Naloxone IM. Z lézí byly izolovány následující patogeny: Staphylococcus spp., Streptococcus spp. a Candida tropicalis. Lokální terapie spočívala v toaletě postižené kůže, aplikaci antibiotik a kožních dezinficiens. Celkově byl aplikován depotní penicilín, vitamíny, probiotika a autogenní kvasinková vakcína. Z hematologických ukazatelů došlo k největším změnám $\mathrm{v}$ celkovém počtu leukocytů a v počtu segmentovaných neutrofilů, u biochemických ukazatelů byly zřejmé nízké hodnoty zinku. I pres nestandardní postupy (častá anestezie v krátkém časovém horizontu, nedodržení doporučení o aplikaci některých léků) a obtížnou manipulaci (agresivní, nezvladatelné zvíře, nemožnost použití fixačního boxu) lze i takovéto př́ípady řešit.

\section{References}

BARONETZKY-MERCIER A 1992: Blutbefunde bei Zootieren nach eigenen Untersuchungen und Literaturangaben. Vet Med Diss Universitat, Giessen, 334 p.

FOWLER ME 1995: Elephants. In: FOWLER ME (Ed.): Restraint and handling of wild and domestic animals. Iowa State University Press, Ames, pp. 257-269

KOCK RA, MORKEL P, KOCK MD 1993: Current immobilization procedures used in elephants. In: FOWLER ME (Ed.): Zoo and wild animal medicine. $3^{\text {th }}$ ed. W. B. Saunders Company, Philadelphia, pp. 436-441

MIKOTA SK, SARGENT EL, RANGLACK GS, PAGE CD 1994a: Anesthesia and chemical restraint. In: MIKOTA SK, SARGENT EL, RANGLACK GS (Eds.): Medical management of the elephant. Indira Publishing House, Michigan, pp. 41-49

MIKOTA SK, SARGENT EL, RANGLACK GS 1994b: The integument. In: MIKOTA SK, SARGENT EL, RANGLACK GS (Eds.): Medical management of the elephant. Indira Publishing House, Michigan, pp. 129135

OLSEN JH 1998: Antibiotic therapy in elephants. In: FOWLER ME and MILLER RE (Eds.): Zoo and wild animal medicine: current therapy. $4^{\text {th }}$ ed. W. B. Saunders Company, Philadelphia, pp. 533-541

RÜEDI D 1995: Elefanten. In: GÖLTENBOTH R, KLÖS HG (Eds.): Krankheiten der Zoo- und Wildtiere. Blackwell Wissenschafts-Verlag, Berlin, pp. 156-189

SALZERT W 1976: Elefanten. In: KLÖS HG, LANG EM (Eds.): Zootierkrankheiten. Verlag Parey, Berlin, Hamburg, pp. 133-135

SCHMITT DL 2003: Proboscidea (Elephants). In: FOWLER ME, MILLER RE (Eds.): Zoo and wild animal medicine. $5^{\text {th }}$ ed. Saunders, Missouri, pp. 541-550 

Plate XIV

Vodička R. et al.: Trunk Pyoderma ... pp. 127-131

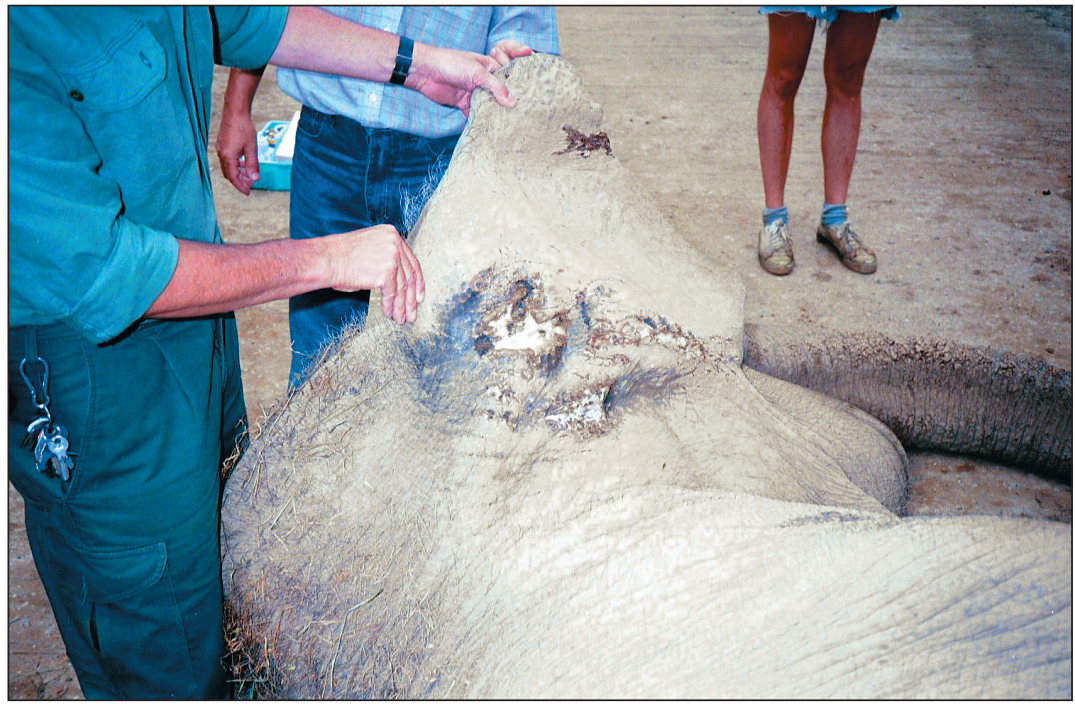

Fig. 1. Immobilization - pus behind the right ear

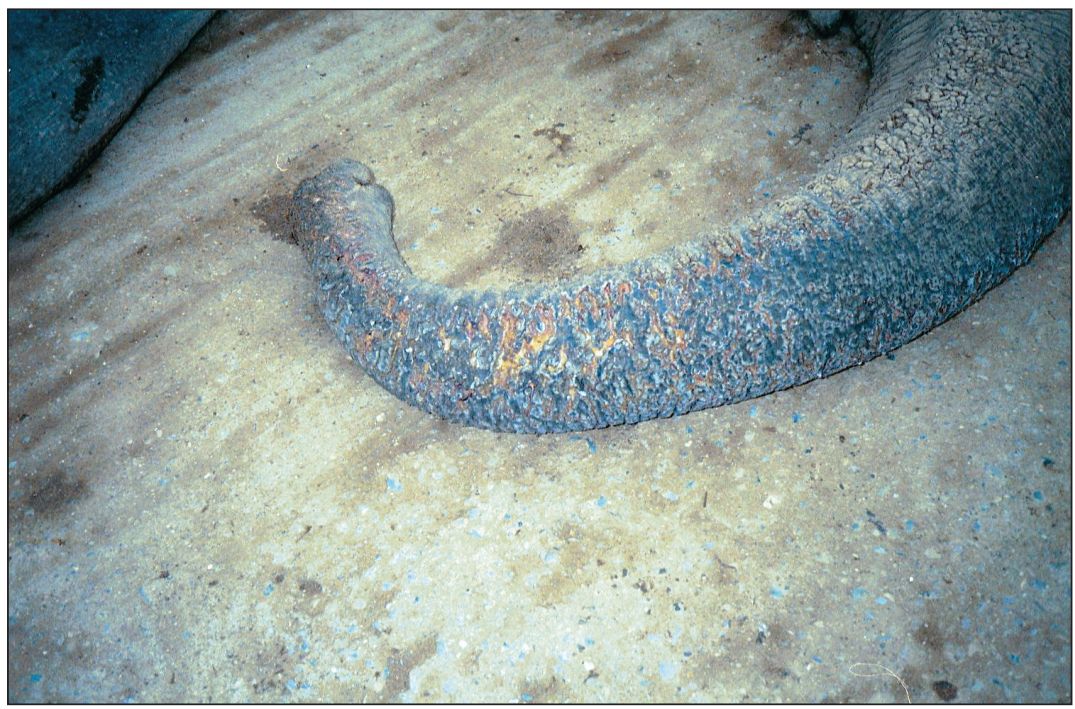

Fig. 2. Immobilization - dry skin and pus on the trunk 


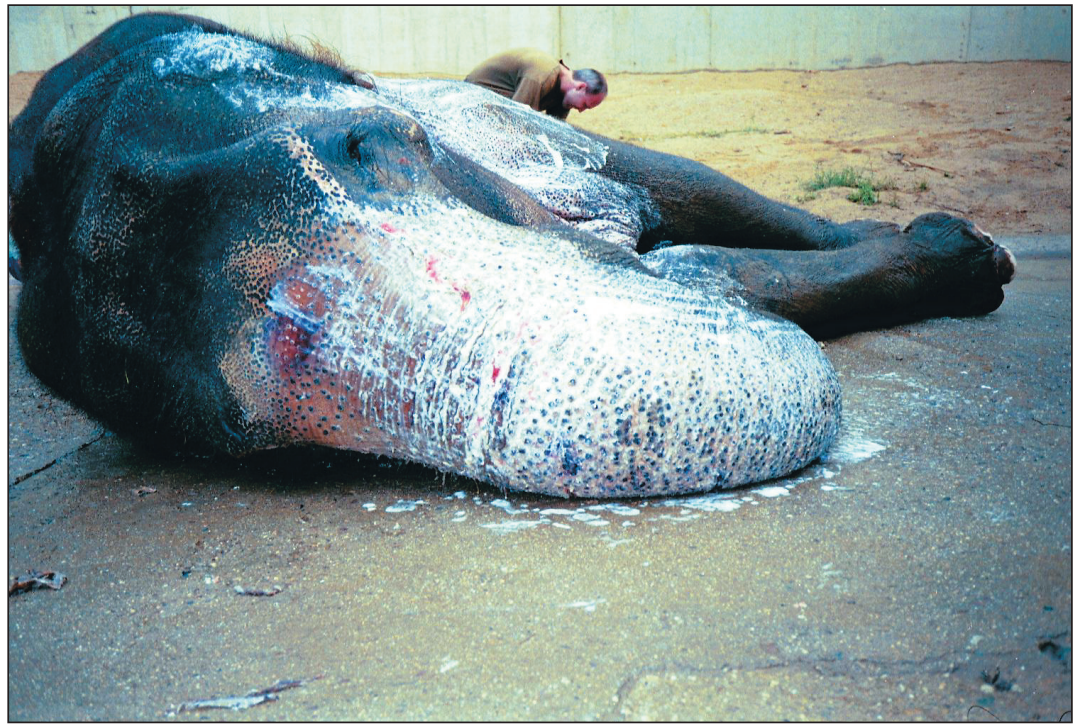

Fig. 3. Immobilization - treatment with Peroxyderm shampoo

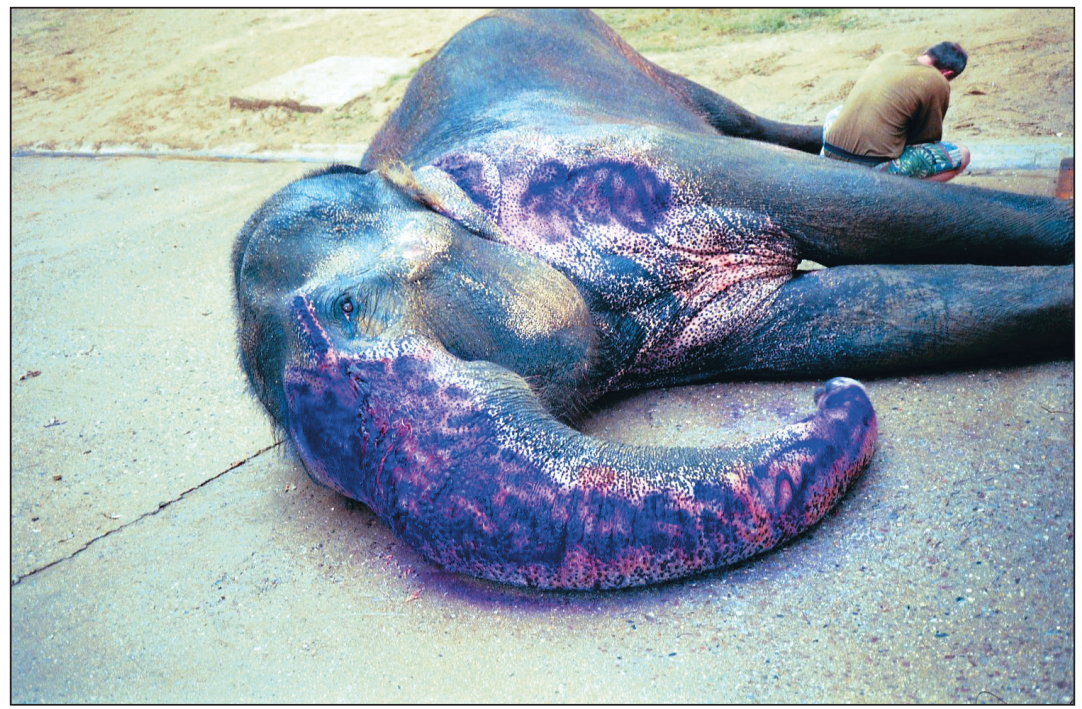

Fig. 4. Immobilization - treatment with Aureomycin GV spray 


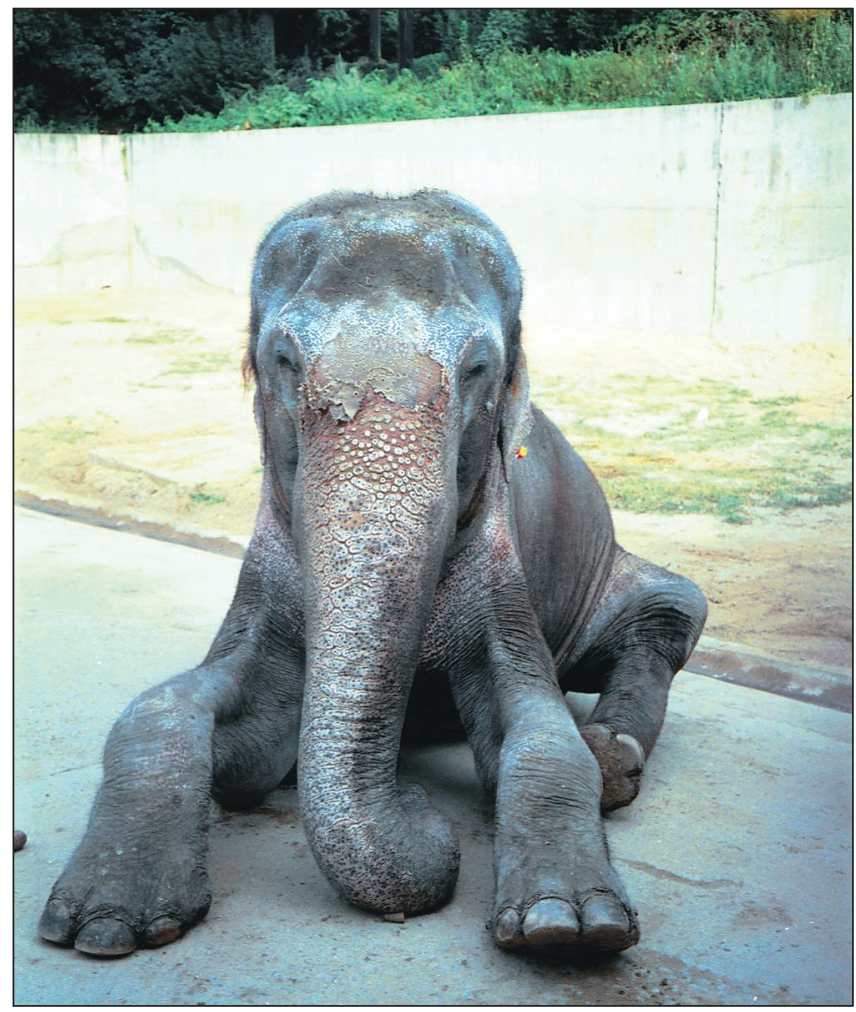

Fig. 5. Immobilization - general view

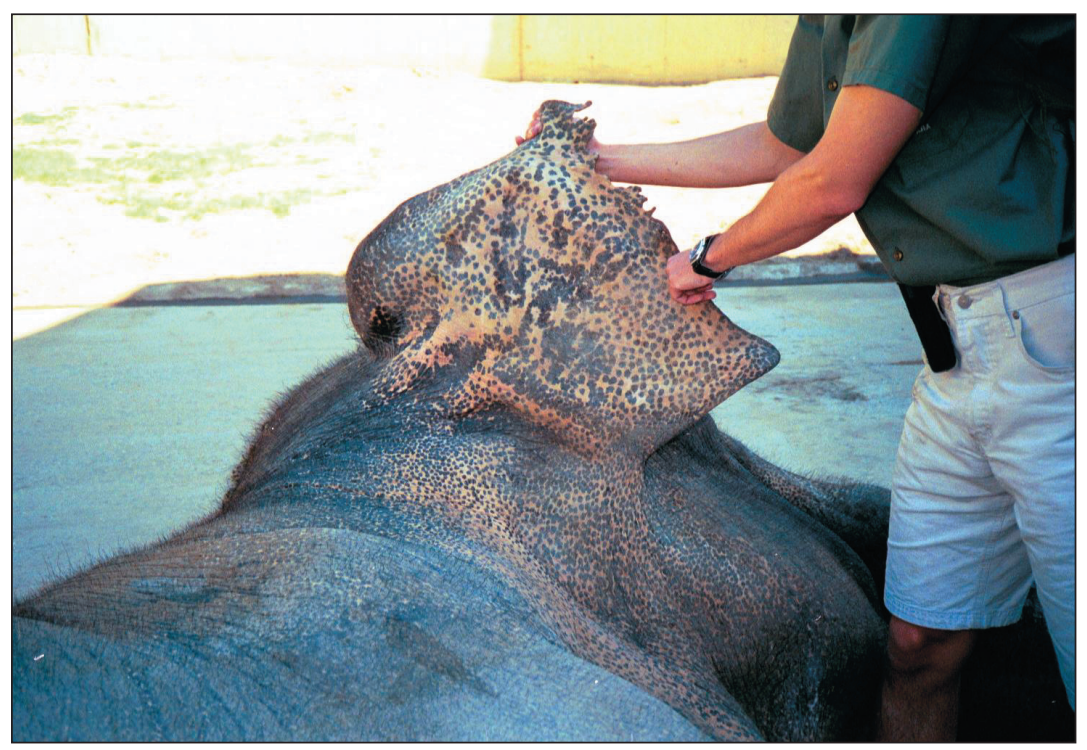

Fig. 6. Immobilization - fully healed skin of the right ear. 